\title{
EDUCAÇÃO E FORMAÇÃO CRÍTICA NA ATUALIDADE
}

\author{
EDUCACIÓN Y FORMACIÓN CRÍTICA EN LA ACTUALIDAD
}

EDUCATION AND CRITICAL FORMATION IN THE PRESENT

\author{
Nilo AGOSTINI ${ }^{1}$ \\ Luzia Batista de Oliveira SILVA ${ }^{2}$
}

\begin{abstract}
RESUMO: Objetiva-se, nesse artigo, discutir a educação e a formação crítica na atualidade, de acordo com a Pedagogia Filosófica de Paulo Freire e dos autores da Teoria Crítica da Sociedade, especialmente, Walter Benjamin e Theodor Adorno. Destacam-se algumas categorias para análise, numa convergência de olhares dos autores, tais como: educação, emancipação, formação, semiformação, oprimidos, opressores, vencidos, vencedores e pensamento crítico. $\mathrm{O}$ desafio de educar para a resistência parece justamente o desafio de saber como despertar a massa para o processo de formação enquanto emancipação, conquista de autonomia e adoção de pensamento crítico, dados os desafios cotidianos.
\end{abstract}

PALAVRAS-CHAVE: Educação. Paulo Freire. Teoria crítica. Formação. Emancipação

RESUMEN: El objetivo de este artículo es discutir la educación y la formación crítica en la actualidad, acorde con la Pedagogía Filosófica de Paulo Freire y de los autores de la Teoría Crítica de la Sociedad, especialmente Walter Benjamin y Theodor Adorno. Se destacan algunas categorías para el análisis, en una convergencia de miradas de los autores, tales como: educación, emancipación, reto de educar para la resistencia parece de hecho el reto de saber cómo despertar la masa para el proceso de formación como emancipación, conquista de autonomía y adopción de pensamiento crítico, puestos los retos cotidianos.

PALABRAS CLAVE: Educación. Paulo Freire. Teoría crítica. Formación. Emancipación.

ABSTRACT: This article aims to discuss education and critical formation today, according to the Philosophical Pedagogy of Paulo Freire and the authors of the Critical Theory of Society, especially Walter Benjamin and Theodor Adorno. Some categories stand out for analysis, in a convergence of the authors' views, such as: education, emancipation, formation, semiformation, oppressed, oppressors, losers, winners and critical thinking. The challenge of educating for resistance seems precisely the challenge of knowing how to awaken the mass to the process of formation as emancipation, the achievement of autonomy and the adoption of critical thinking, given the daily challenges.

${ }^{1}$ Universidade São Francisco - (USF), Itatiba - SP - Brasil. Docente no Programa de Pós-Graduação Stricto Sensu em Educação. ORCID: https://orcid.org/0000-0001-5657-8651. Lattes: http://lattes.cnpq.br/3355200763911829 E-mail: nilo.agostini@usf.edu.br

${ }^{2}$ Universidade São Francisco - (USF), Itatiba - SP - Brasil. Docente no Programa de Pós-Graduação Stricto Sensu em Educação. ORCID: https://orcid.org/0000-0003-4880-7199. Lattes: http://lattes.cnpq.br/5030940137585680 E-mail: luzia.silva@usf.edu.br

RIAEE - Revista Ibero-Americana de Estudos em Educação, Araraquara, v. 14, n. esp. 4, p. 1977-1992, dez., 2019. E-ISSN: $1982-5587$. DOI: https://doi.org/10.21723/riaee.v14iesp.4.12922 
KEYWORDS: Education. Paulo Freire. Critical theory. Formation. Emancipation.

\section{Introdução}

Discute-se a educação e a formação crítica na atualidade de acordo com o educador e filósofo brasileiro Paulo Freire, e os autores da teoria crítica da sociedade, especialmente, Walter Benjamin e Theodor Adorno, colocando em pauta a formação crítica e o processo de emancipação dos sujeitos.

A educação na obra de Paulo Freire é uma categoria chave do seu pensamento. Sua obra se constitui em um campo fértil e um manancial de aprendizados práticos e teóricos. A obra de Walter Benjamin tem, por sua vez, um potencial criativo e formativo, fundamental para o campo da educação, podendo-se explorá-la sob variados vieses ou a partir das inúmeras temáticas, categorias e dimensões, como a ética, a estética, a linguagem, a arte, a história, a filosofia da história, elementos fundamentais para se pensar os desafios educacionais do presente. Já a obra de Theodor Adorno é um convite aberto para pensarmos e repensarmos as ações na esfera da educação, cujo pensamento crítico é um convite para enxergarmos as mazelas e os obstáculos ao processo educacional, para sairmos de uma educação deformativa, como a semiformação, e alcançar a formação como um processo de emancipação do sujeito.

Nesse artigo, a opção foi uma abordagem educativa, através de uma pesquisa bibliográfica, a partir, especialmente, das categorias dos autores supracitados: vencidos e vencedores da história, oprimidos e opressores, semiformação, formação e emancipação.

\section{A educação na perspectiva freiriana dos condenados da terra}

A obra Os condenados da terra, de Frantz Fanon (1968), é uma referência valiosa para Paulo Freire sobre a condição humana no Brasil e no mundo. Ao dar-se conta da grande contradição opressores-oprimidos, Freire traça uma perspectiva a partir dos "condenados da terra", objetivando discutir os males sofridos pela humanidade, que é cotidianamente negligenciada, esquecida e roubada enquanto vocação histórica.

Em sua leitura do mundo, Freire considera que os esmagados e vencidos detêm sua atenção preferencial, tornando-se o ponto de partida de sua práxis, enquanto reflexão e ação em vista da transformação do mundo. Seu olhar contempla as realidades históricas, marcadas pela 
violência dos exploradores capitalistas e dos poderosos que produzem mercadorias para serem consumidas vorazmente pelas pessoas, enquanto outros sequer podem consumir o necessário para viver com dignidade, acentuando, portanto, um processo de desumanização que parece não ter fim.

Deste olhar, fruto de uma inserção crítica na realidade, toma forma uma consciência que se traduz em tarefa histórica, na luta pela humanização, pela libertação da opressão de tantos que têm sua dignidade tolhida, numa morte em vida, uma existência apagada, esquecida e excluída, cujo destino não é dado, “mas resultado de uma 'ordem' injusta que gera a violência dos opressores e, esta, o ser menos" (FREIRE, 2014b, p. 41).

Ante a desumanização que sofrem os demitidos da vida, Freire aponta para uma luta de transformação que seja "criadora de vida", a fim de deter a "morte em vida", ou seja, "a vida proibida de ser vida" (FREIRE, 2014b, p. 233). Construída e conquistada pela práxis, essa transformação faz-se com o oprimido e não para ele. Esta práxis transformadora requer, segundo Freire (2014b, p. 42), um "aprendizado" que "tem de partir dos 'condenados da terra', dos oprimidos, dos esfarrapados do mundo e dos que com eles se solidarizam".

O caminho pedagógico passa assim a ser esboçado como conquista, sendo que o primeiro passo é o de tomar consciência de que o opressor está hospedado no próprio oprimido, à medida que este se identifica com ele e reproduz a opressão sofrida, tornando-se um subopressor. Por isso, encontra-se numa "aderência" ao opressor, porque "imerso" na realidade opressora com a qual se identifica e até a defende. Para Freire (2014a, p. 96), esta "consciência hospedeira da opressão" provoca a dispersão, a acomodação, o ajustamento do oprimido que normaliza a submissão num cenário de mutismo e de alienação e numa perspectiva antidialogal.

Descobrir-se oprimido, tomar consciência da aderência ao opressor, enquanto seu hospedeiro, constitui-se no primeiro passo pedagógico de uma consciência crítica por parte do oprimido. Consequentemente, este inaugura uma práxis para reverter esta contradição opressoroprimido, num reconhecimento de sua real situação, lançando-se em busca da autonomia, como conquista feita passo a passo, assumindo suas responsabilidades no concreto da história. Freire descreve esta conquista como busca permanente na conquista da liberdade.

A liberdade, que é uma conquista, e não uma doação, exige uma permanente busca. Busca permanente que só existe no ato responsável de quem a faz. Ninguém tem liberdade para ser livre: pelo contrário, luta por ela precisamente porque não a tem. Não é também a liberdade um ponto ideal, fora dos homens, ao qual inclusive eles se alienam. Não é ideia que se faça mito. É condição indispensável ao movimento de busca em que estão inscritos os homens como seres inconclusos (FREIRE, 2014b, p. 46). 
Segue-se uma ação transformadora que se efetivará através de uma práxis libertadora que se concretiza na solidariedade do reconhecimento do outro, numa consciência para o outro e com o outro, num cultivo de relações fundamentais homem-mundo-outro-Criador (FREIRE, 2014a, p. 55-56, 2007, p. 62-64). Trata-se de um ser humano enquanto pessoa aberta à realidade e não submisso a ela. Este estabelece uma relação com o mundo não por meros contatos, como os animais, mas como alguém que interfere na realidade e, por ela desafiado, modifica-a. Deixa de ser mero objeto, assume-se como sujeito. Não age como expectador, mas desdobra a sua capacidade criadora, como ser da história e da cultura, numa inserção crítica na realidade que, enquanto ser da práxis, é capaz de "reflexão e ação sobre o mundo para transformá-lo" (FREIRE, 2014b, p. 52).

Ao "tomar posse da realidade", como sujeito e não como objeto, o ser homem vai se tornando capaz de um "conhecimento crítico" que concomitantemente se faz "compromisso histórico", o que implica numa "inserção histórica" em que "os homens assumem o papel de sujeitos que fazem e refazem o mundo" (FREIRE, 2008, p. 29-33).

Este processo, que é de conscientização, constitui para Freire (2008, p. 46) o "primeiro objetivo de toda a educação: antes de tudo provocar uma atitude crítica, de reflexão, que comprometa a ação". Supera os níveis de consciência ingênua, mágica e fatalista, com o cuidado de não cair em versões sectárias ou até mesmo fanáticas, para que se mantenha sempre uma atitude crítica nos embates da história, sem que haja recaída para a acomodação, o ajustamento e a mera adaptação.

Estamos no âmago da conscientização que propõe uma educação enquanto processo de democratização fundamental. Esse processo não é para um período apenas; antes, é um processo permanente que nos acompanha em toda a nossa existência. Freire (2008, p. 46) tem enfatizado que, sendo uma "atitude crítica dos homens na história, não terminará jamais", acrescentando que "a conscientização, que se apresenta como um processo num determinado momento, deve continuar sendo processo no momento seguinte, durante o qual a realidade transformada mostra um novo perfil”".

Não existindo fora da práxis, a educação que passa pela conscientização une consciência e mundo, numa inserção crítica na história e num despertar para o papel de sujeitos; requer conhecimento crítico, exige compromisso de transformação, realiza-se através do engajamento. A realidade não se transforma por si mesma, sendo os próprios oprimidos os primeiros sujeitos da ação. Por isso, é pedagogia dos oprimidos, "a pedagogia dos homens empenhando-se na luta por sua libertação" (FREIRE, 2014b, p. 55). 


\section{Benjamin: vencidos e vencedores e a educação}

A educação na obra de Walter Benjamin pode ser pensada a partir de inúmeras temáticas, categorias e dimensões, como a ética, a estética, a linguagem, a arte, a história, a filosofia da história e muitas outras opções. Nesse artigo, a opção foi uma abordagem educativa a partir especialmente das categorias vencidos e vencedores da história, a fim de aproximarmos a obra do filósofo alemão com a obra do educador e filósofo brasileiro Paulo Freire, especialmente nas categorias de oprimidos e opressores e no que tange às minorias no Brasil.

Para além da barbárie dos poderosos, em seu cortejo triunfal que "conduzem por sobre os corpos dos que estão prostrados no chão" (BENJAMIN, 2016, p. 244), no fragmento dessa tese 7, o autor propõe "escovar a história a contrapelo". Numa crítica à sociedade burguesa que convive e tolera a existência da marginalização, da corrupção e de toda sorte de contravenção, o filósofo berlinense assume o ponto de vista dos vencidos, consciente do triunfo dos poderosos e de sua barbárie.

Para Löwy (2005, p. 73), isto implica em ser "solidário com os que caíram sob as rodas de carruagens majestosas e magníficas denominadas Civilização, Progresso e Modernidade”, numa "recusa em se juntar, de uma maneira ou de outra, ao cortejo triunfal que continua ainda hoje a marchar sobre aqueles que jazem por terra".

A barbárie, da qual Benjamin se refere, não é somente obra de um passado, mas faz parte do "contínuo" da história, que insiste em se fazer presente em nossos dias, no drama dos pobres, oprimidos, silenciados, relegados aos porões de uma modernidade que entroniza a mercadoria e espolia o ser humano.

Importa, para esta modernidade, o domínio do capital, que instrumentaliza as tecnologias e coloca a seu serviço a mídia. A técnica, como promessa de saída das garras do capitalismo nefasto e das permanências históricas, parece distante da realidade, dado que "os sonhos de um mundo melhor graças à técnica latejam adormecidos em seu fracasso" (MATE, 2011, p. 47). Destarte, “o capitalismo foi um fenômeno natural com o qual um novo sono repleto de sonhos se abateu sobre a Europa e, com ele, uma reativação das forças míticas" (BENJAMIN cf. TIEDEMANN, 2009, p. 20).

Não existe uma história linear em que os acontecimentos estão inscritos de modo acomodatício como se houvesse um progresso contínuo. A história, na proposta de Benjamin, é escrita a partir dos que foram interrompidos em sua história, que não tiveram uma continuidade, os que foram vencidos, que serviram para construir o presente; às custas de suas 
vidas sugadas e de seus ideais derrotados, ergue-se a civilização atual, sua modernidade e seu progresso.

Portanto, não há como expressar "empatia com o vencedor", em sua barbárie, num conformismo ou fatalismo, num historicismo servil, autômato, mecânico, como quem se curva diante do poder dos que só fazem aumentar o número das vítimas.

No processo de modernização de mundo, a fantasmagoria, segundo Mate (2011, p. 47 48), age por conta própria, porque "o fetichismo da técnica consistiria em fazer-nos crer que a linha de montagem exige um tipo de trabalhador robotizado", dado que "a técnica moderna tem algo que a produção industrial não tinha. Há uma mudança substancial no caráter mercadoria. E, para apreciá-la, não temos que ir até a fábrica, mas até às vitrines”. Ao capitalismo vigente, modernizar significa disponibilizar mercadorias para consumo em tempo real.

E, para além de uma resignação fatalista, somos instigados por Benjamin a nos postarmos a serviço da emancipação das classes oprimidas, longe das ilusões do progresso e das filosofias burguesas da história, e alimentar um alto grau de criticidade.

Benjamin faz soar o "alarme de incêndio" (Feuermelder), título de um ensaio curto que se encontra no livro Rua de mão única, que, segundo Löwy (2005, p. 32), "é um dos mais impressionantes textos de Walter Benjamin", curto e direto, constituindo-se num "aviso de incêndio dirigido a seus contemporâneos". Com Benjamin, fica escancarada a irracionalidade do fascismo, que combina progresso técnico com regressão social. Compreendemos, então, que Löwy (2002, p. 205) enfatize a necessidade de enxergarmos e avaliarmos o século XX, "caracterizado pela imbricação estreita entre a modernidade e a barbárie", o que atesta "precisamente a fonte do valor singular da filosofia benjaminiana da história".

Trata-se de uma expressão, um apelo de Benjamin para alertar sobre a necessidade de apagarmos as chamas das loucuras que causarão a destruição de seres humanos como o pavio que um dia pegou fogo, incendiando os ânimos à guerra, tal como na Primeira e na Segunda Guerra Mundial, cujas permanências históricas continuam a incitar os ânimos quando eles não são assimilados, colocados em xeque e analisados, possibilitando que as vítimas e os vencedores da história continuem a sua caminhada desenfreada com e pelo capitalismo, ainda que por cima dos escombros e dos mortos. O pavio também pode significar a dominação contínua da burguesia no mundo capitalista, sendo fundamental a figura do revolucionário, o rebelde, a fim de apagar este pavio que acenderá a pólvora destruidora, porque é aquele que tem consciência dos riscos e dos perigos, mas também é aquele que sabe das possibilidades de uma saída. 
A história dos fatos contada linearmente pelos poderes estabelecidos, fetichista e historicista reifica as relações humanas e sociais, transformando-as em meras coisas sociais, fetichizadas em mercadorias, pressupondo a extração da mais valia como parte do processo capitalista de produção (BUBBO, 2010, p. 14-15). Este processo abre caminho para a exploração e sua barbárie, com a procissão triunfal dos poderosos que pretendem impor a sua superioridade como um contínuo na história. Cabe, segundo Benjamin (2016, p. 244-145), em meio ao "tempo de agora" (tese 14), descobrir o kairós, o tempo histórico pleno, no qual é quebrado ou interrompido o "continuum da história" (tese 15), ou seja, o cortejo triunfal dos vencedores. Para este processo, terá que intervir a educação que, para Benjamin, encontra pontos de convergência na experiência e na memória, porque o "tempo de agora" (Jetzt) tem a ver com o tempo artístico, que possibilita uma abertura para as novidades, a criatividade, as inovações do pensamento, o tempo que pode trazer surpresas, o inusitado, assinalando o tempo aberto ou o tempo em estado de abertura.

Contudo, devemos sair do "tempo do inferno", que numa leitura teológico-filosófica, segundo Benjamin, é o tempo que em nome da modernidade se cometem atrocidades, pois "trata-se [...] do fato de que o rosto do mundo, a imensa cabeça, nunca muda em relação àquilo que é o mais novo, que este 'mais novo' permanece sempre igual em todas as suas partes". Então, "eis o que constitui a eternidade do inferno e o desejo de novidade dos sádicos. Determinar a totalidade dos traços nos quais este 'moderno' se manifesta, significa representar o inferno" (BENJAMIN cf. TIEDEMANN, 2009, p. 20).

Quanto à memória, supõe-se uma experiência autêntica, o que é determinante na educação. Apreendida como "a mais épica de todas as faculdades” (BENJAMIN, 2016, p. 210), a memória referencia-se mais à rememoração, à reminiscência do que aquilo que foi vivido. Importa o "tecido de sua rememoração", segundo explica Benjamin (2016, p. 38), interligando história individual e coletiva, o inconsciente da mente humana e o espaço-tempo de nossa história, corpo e imagens a serem perscrutadas. "Esta perscrutação dialética e a presentificação das circunstâncias do passado são a prova da verdade da ação presente", capaz de "acender o pavio do material explosivo que se situa no ocorrido" (BENJAMIN, 2009, p. 437). A memória protege nossas impressões, qual escrita de imagens, de rastros e de pistas, que permite desvendar mistérios, entrever as profundezas da alma e da existência, na escuta dos ecos do passado e na percepção da possibilidade de modificar o mundo.

A memória traz a necessidade de preservar as experiências da vida, ante o refreamento da experiência autêntica, sendo possível "despertar no passado as centelhas da esperança" (BENJAMIN, 2016, p. 244) que podem "incendiar a pólvora no presente" (LÖWY, 2005, p. RIAEE - Revista Ibero-Americana de Estudos em Educação, Araraquara, v. 14, n. esp. 4, p. 1977-1992, dez., 2019. E-ISSN: $1982-5587$. 
66). Decorre daí uma "responsabilidade na formação da população", o que leva, segundo Colom e Ballester (2016, p. 101), à seguinte postura: "Temos que transformar as instituições e as práticas culturais para superar a coerção burguesa sobre os indivíduos [...], para construir uma sociedade mais justa. A transformação social deve ser um dos objetivos da cultura, da educação”. A pedagogia benjaminiana está embasada numa concepção cultural e humanística e endereçada a uma "crítica cultural e instrumento de transformação social" (COLOM; BALLESTER, 2016, p. 198).

Esta crítica que advém da percepção benjaminiana é sobretudo endereçada à pedagogia burguesa, pois sua ação aliena, deforma e destrói a pessoa humana, sendo rebaixada e colocada à serviço da burguesia. Tem, assim, um caráter desumanizador; leva ao individualismo, adestra para ter resultados futuros e aliena-se ante o presente, suprimindo-o. Torna o indivíduo um ser a-histórico, associal e, consequentemente, acrítico, sem ligação com uma coletividade, colonizando suas consciências. Benjamin (2008) a chama de "pedagogia colonial", ao transformar crianças e jovens em mercadoria oferecida às classes dominantes, a serem submetidos a uma pedagogia do poder, do domínio e da colonização, educadas, segundo Colom e Ballester (2016, p. 200), "sem ter em conta sua verdadeira realidade pessoal e, menos ainda, o contexto social do qual emergem e no qual deveriam formar-se".

A experiência em Walter Benjamin, de acordo com Fred Rush (2008), rompe com o conceito de experiência em Kant, carregado de barreiras. Para Benjamin, a intenção cognitiva está relacionada na experiência da faculdade mimética, possibilitando um "saber sensível". A experiência pode produzir e também perceber semelhanças não-sensíveis (linguagem e escrita), mediante um comportamento sensível e qualitativo (BENJAMIN, 2009, p. 18-19).

Em Walter Benjamin, podemos falar de uma "experiência tradicional" que sempre surpreende por trazer algum tipo de conhecimento e que pode ser partilhado com pessoas; de uma "experiência cientifica", que diz respeito aos saberes racionalizados, sistematizados e que se configuram como saberes objetivos; a "experiência do choque" que se configura como aquela que, de acordo com Chaves (2007), só acontece numa situação traumática. Alguns ensaios de Benjamin atestam esta situação traumática. Pode-se também relacioná-la com algum tipo de sofrimento provocado no tempo presente, carregado de loucura numa sociedade capitalista, a qual vive num clima de austeridade neoliberalista. Trata-se daquele momento em que a verdade que estava oculta ou encoberta por uma outra história ou detalhe(s) capcioso, fantasmagórico, se contradiz e se revela, acaba aparecendo, o que no dizer popular significa dizer que "caiu a ficha". 


\section{Adorno: uma proposta de educação para a emancipação}

Adorno, na obra Dialética negativa (1998), pauta seu pensamento na necessidade de rejeitar qualquer visão sistêmica ou totalizante da sociedade, ideia esta que atravessa a sua obra. A Dialética Negativa é a dialética que não opera mais com uma síntese positiva do objeto de análise, porque uma síntese sempre levará a outra síntese num processo contínuo; na atualidade, torna-se inaceitável escrever sobre certas coisas e, ao mesmo tempo, é também inaceitável não escrever sobre elas, como o exemplo a seguir, escrever e não escrever mais poemas depois de Auschwitz:

A crítica cultural defronta-se com o último degrau da dialética entre cultura e barbárie: é barbárie escrever um poema após Auschwitz, e isso também corrói o conhecimento que afirma por que hoje se tornou impossível escrever poemas. Enquanto o espírito crítico permanecer em si mesmo em autossuficiente contemplação, ele não será capaz de enfrentar a absoluta reificação que, entre os seus pressupostos, teve o progresso do espírito como um dos seus elementos e que hoje se prepara para sugá-lo completamente (ADORNO, 1998, p. 26).

O pensamento de Adorno desemboca na defesa do potencial do pensamento crítico e da emancipação dos seres humanos. Permite esclarecer os meandros da modernidade, enquanto portadora de uma problemática reveladora da barbárie, sob a capa ilusória da semiformação, cuja saída é colocar a descoberto as falsas e superficiais formações, dado que a semiformação alcança todos os níveis de formação e todas as dimensões da vida humana, não poupando nenhuma área de conhecimento. “A barbárie encontra-se no próprio princípio civilizatório”, como "tendência dominante do progresso, do esclarecimento, do humanismo supostamente crescente" (ADORNO, 2012, p. 120). Contudo, no processo de educação e formação, é fundamental abdicar da ilusão de que é possível um programa ser gestado para evitar a barbárie(s), tampouco acreditar que existe a priori uma autoconsciência e uma resistência que podem ser programadas. A barbárie é a queda, o tipo de queda que pede atenção contínua na educação a fim de conter processos de desumanização, por exemplo, aqueles que assistimos cotidianamente na sociedade e até no âmbito educacional. É nesse ponto que a educação para o pensamento crítico pode ser um elemento da não barbárie, da não semiformação.

$\mathrm{Na}$ verdade, Adorno acredita que uma educação crítica e emancipadora pode permitir a identificação de consciências desprovidas da capacidade de uma autorreflexão crítica, capazes de cometer atrocidades, como o assassinato planejado de milhões de pessoas inocentes nos campos de concentração nazistas, na guerra turca contra os armênios ou nas bombas lançadas sobre a população japonesa, na destruição de vidas indígenas como no processo de colonização 
da América Latina, no povoamento do Brasil, na destruição, violência, escravização e mecanismos de crueldade e barbárie nas penas e castigos aplicados aos negros escravizados; e, ainda hoje, seus descendentes continuam a luta por respeito e reconhecimento de sua contribuição para o país, considerando que o tratamento é diferente entre brancos e negros, sendo as pessoas negras as que mais perdem a vida no país. Damo-nos conta de um nacionalismo agressor tão presente em nossa história recente, num nexo histórico que se perpetua até nossos dias.

Uma educação que coloque em prática o Pensamento crítico como vigilância de si e do contexto social parece fundamental porque "aquele que pensa põe resistência [...]. Só pensa quem não se limita a aceitar passivamente o desde sempre dado; pensar é ser ativo, ir contracorrente, contra o instituído, é querer contar a história de um objeto de uma outra maneira. Há uma potencialidade de intervenção no pensamento crítico" (ADORNO, 1995, p. 62).

Educar para que Auschwitz não se repita é educar contra as monstruosidades que podem aflorar em qualquer sociedade, sendo fundamental buscar novas formas de apontar os erros cometidos no passado que fizeram com que a barbárie fosse cultivada sem uma resistência capaz de barrá-la. Esta pode ser uma meta educacional para o presente. Sejamos vigilantes, pois persiste “a ameaça de uma regressão à barbárie” (ADORNO, 2012, p. 119).

Faz-se necessário um esclarecimento sobre os fatos, bem como sobre a dimensão da barbárie perpetrada. Urge criar, segundo Adorno (2012, p. 123), "um clima em que os motivos que conduziram ao horror tornem-se de algum modo conscientes", tais como "comportamentos autoritários e autoridades cegas", a falta de "autodeterminação" quando se esfacelam os impérios, a incapacidade de viver a "liberdade" em meio aos vazios nos tempos de transição e a fácil cooptação de populações inteiras pelo potencial autoritário de tresloucados fascistas e seu caráter manipulador.

Enquadrar as pessoas, tornando-as cegas, é o objetivo do caráter manipulador dos que querem impor um mundo administrado. Tentativas de enquadrar o povo são muito frequentes, transformando as pessoas em material de manobras, sem autodeterminação, amorfas. Este processo atinge a própria consciência das pessoas que, segundo Adorno (2010, p. 9), renunciando à sua autodeterminação, "prende-se, de maneira obstinada, a elementos culturais aprovados", numa "onipresença do espírito alienado", resultando numa semiformação socializada que "passou a ser a forma dominante da consciência atual".

Advinda das entranhas da sociedade burguesa, a semiformação cria pessoas cegas e mutantes, de fácil manipulação pela indústria cultural, perdendo sua humanidade; adaptam-se, conformam-se e agem, suscetíveis à domesticação e submissão. Na semiformação, instala-se a RIAEE - Revista Ibero-Americana de Estudos em Educação, Araraquara, v. 14, n. esp. 4, p. 1977-1992, dez., 2019. E-ISSN: 1982-5587. 
acomodação, perpetua-se a deformidade e a sociedade apresenta-se inteiramente adaptada. A real formação "se congela em categorias fixas - sejam elas do espírito ou da natureza, de transcendência ou de acomodação -, cada uma delas, isolada, se coloca em contradição com o seu sentido, fortalece a ideologia e promove uma formação regressiva" (ADORNO, 2010, p. $11)$.

Instala-se a dominação progressiva pela adaptação, o sujeito se deixa submeter, aceita a autolimitação, buscando garantir a sua autoconservação. Aceita os limites da sociedade cega e restritiva, numa conformação ao poder estabelecido. Instala-se uma falsa racionalidade, dando origem a uma consciência e a um espírito igualmente falsos. Este processo levou à degradação, instalando uma práxis heterônoma, escorregando na ideologia, numa traição da formação em si mesma, cooptados e entregues a um mundo organizado, administrado, à mercê da voracidade capitalista e de seus processos de desumanização. O próprio proletariado é refém do sistema e passa pelo processo de integração.

Por inúmeros canais, fornecem-se às massas bens de formação cultural. Neutralizados e petrificados, no entanto, ajudam a manter no devido lugar aqueles para os quais nada existe de muito elevado ou caro. Isso se consegue ao ajustar-se o conteúdo da formação, pelos mecanismos de mercado, à consciência dos que foram excluídos do privilégio da cultura [...]. A estrutura social e sua dinâmica impedem a esses neófitos os bens culturais que oferecem ao lhes negar o processo real da formação (ADORNO, 2010, p. 16).

Diante desse mundo da semicultura ou semiformação, Adorno (2010, p. 39) é enfático ao afirmar que "a única possibilidade de sobrevivência que resta à cultura é a autorreflexão crítica sobre a semiformação, em que necessariamente se converteu"; para ele, "impõe-se, nesta atual hora histórica, a reflexão sobre a formação". Ele ressalta a necessidade de leitura dos mecanismos que agem sobre as pessoas, despertando a consciência geral sobre sua influência, buscando impedir a barbárie que se expressa através do ódio e da fúria agressiva.

Adorno (2012, p. 121) é claro ao afirmar que "a educação tem sentido unicamente como educação dirigida a uma autorreflexão crítica". Isto significa preparar as pessoas para a autodeterminação, sendo a autonomia "o único poder efetivo" contra o horror dos holocaustos de ontem e de hoje, ou seja, a capacidade de reflexão que, livre das heteronomias, diz não à participação em atrocidades, sendo a desbarbarização "um dos objetivos educacionais mais importantes" (ADORNO, 2012, p. 126).

Além do sistema educacional, importa estarmos atentos ao estado da consciência, pois esta pode estar mutilada de muitas formas, sendo fundamental, então, prestar atenção a todas as formas de instrumentalização das massas, de vigilância das pessoas. O esclarecimento é 
importante como forma de resistência, decifrando os mecanismos subjacentes que produzem uma massa amorfa, conformada, fruto da manipulação.

O esclarecimento em Adorno e Horkheimer é uma categoria herdada de Immanuel Kant que ganha sentido ambíguo, podendo expressar-se positivamente numa necessidade de alguém se tornar autossuficiente, esclarecido; também pode ter um sentido negativo, podendo expressar um engano diante das catástrofes do progresso capitalista. Na obra Dialética do Esclarecimento, Adorno e Horkheimer (1985, p. 11) pontuam que é fundamental investigar a fim de "[...] descobrir por que a humanidade, em vez de entrar em um estado verdadeiramente humano, está [a cada dia] se afundando em uma nova espécie de barbárie" (1985, p. 11).

Wiggershaus (2010, p. 357) comenta a obra dos frankfurtinanos a respeito dessa ambiguidade do termo emancipação que pode tanto incluir como excluir. Os filósofos parecem que "[...] não desejam jogar fora o bebê com a água do banho, mas simplesmente mostrar a ambiguidade da Aufklärung", numa advertência fundamental de que "o esclarecimento é totalitário como qualquer outro sistema" (ADORNO, 1985, p. 32); e "[...] nada mais pode ficar de fora, porque a simples ideia do fora é a verdadeira fonte de angústia" (ADORNO, 1985, p. 26). Por isso, o que não pode ser calculado nem tem utilidade torna-se suspeito, até "o número tornou-se o cânon do esclarecimento" (ADORNO; HORKHEIMER, 1985, p. 20); logo, tudo parece se reduzir ao número, ao uno, a uma totalidade.

Cabe, portanto, superar o estágio de uma consciência coisificada, de uma fetichização da técnica, para que não soçobre a capacidade de amar, de se relacionar com os outros, a fim de que a frieza seja apagada e sobrevenha uma vida digna para todos.

A frieza é um sentimento humano; a frieza burguesa é um sentimento humano de uma determinada classe social, especialmente daquele que pode fazer diferente, contribuir e resistir às barbáries, mas não o faz; e quando deixamos de nos perguntar como é possível sobreviver depois de toda injustiça, violência e sofrimento? Em se tratando de um país como o Brasil, em que pesem suas benesses e belezas naturais e humanas, como continuar cego perante as práticas de injustiça, violência e sofrimento na atualidade? "O sofrimento perenizante tem tanto direito à expressão quanto o martirizado tem de berrar; por isso é bem provável que tenha sido falso afirmar que depois de Auschwitz não é mais possível escrever nenhum poema" (ADORNO, 2009, p. 300). Diante de tais absurdos, pode-se até questionar os que têm ou não direito à vida. Todavia, a educação ou formação geral pressupõe espiritualização e a sensibilidade para permanecer em estado de alerta, porque "a frieza, característica da natureza humana, possibilitou a realização de Auschwitz"(ADORNO, 1995, p. 133-134). 
É preciso fortalecer "a resistência por meio do esclarecimento" (ADORNO, 2012, p. 127), mostrando "as possibilidades concretas da resistência" (p. 136), buscando "a dissolução dos mecanismos de repressão e de formações reativas que deformam nas próprias pessoas sua aptidão para a experiência" (p. 150). A isso se alia uma consciência que pensa a vida conectada à realidade, voltada "à capacidade de fazer experiência" (p. 151), o que faz Adorno afirmar: "A educação para a experiência é idêntica à educação para a emancipação" (p. 151).

\begin{abstract}
A única concretização efetiva da emancipação consiste em que aquelas poucas pessoas interessadas nesta direção orientem toda a sua energia para que a educação seja uma educação para a contradição e para a resistência [...]. Assim, tenta-se simplesmente começar despertando a consciência quanto a que os homens são enganados de modo permanente, pois hoje em dia o mecanismo da ausência de emancipação é o mundus vult decipi em âmbito planetário, de que o mundo quer ser enganado. A consciência de todos em relação a essas questões poderia resultar dos termos de uma crítica imanente, já que nenhuma democracia normal poderia se dar ao luxo de se opor de maneira explícita a um tal esclarecimento (ADORNO, 2012, p. 183).
\end{abstract}

\title{
Considerações finais
}

O desafio de educar para a resistência parece justamente o desafio de saber como despertar a massa para o processo de formação enquanto emancipação, conquista de autonomia e adoção de pensamento crítico, dados os desafios cotidianos.

A formação cultural em Adorno está para além de um espaço de sala de aula, um espaço restrito para o educar, porque "a formação cultural só pode ser adquirida mediante esforço espontâneo e interesse, não pode ser garantida simplesmente por meio de frequência de cursos" (ADORNO, 1995, p. 64).

Esforço e interesse do sujeito, mas como trabalhar na educação para desmistificar a promessa que a sala de aula é a solução para todos os problemas formativos? Como trabalhar na educação numa sociedade em que um grupo elitista luta para manter-se como eterno opressor, com direito a continuar mantendo a vítima cega, o oprimido que se identifica com o opressor e se sente incapaz de enxergar os elementos diferenciadores dessa relação?

A emancipação corresponde "à capacidade de se abrir a elementos do espírito, apropriando-os de modo produtivo na consciência, em vez de se ocupar com os mesmos unicamente para aprender" (ADORNO, 1995, p. 64). Contudo, se a formação sempre foi um elemento importante em toda cultura, como pensá-la mediante uma perspectiva freireana, benjaminiana ou adorniana? 
Em síntese, aqui trazemos mais uma categoria de Benjamin que nos encoraja a tomar uma posição na educação, ou seja, como "escovar a história a contrapelo" ou como escovar nossa história a contrapelo? Como contribuir para que o oprimido perceba a opressão em que se encontra e o opressor não encontre tão facilmente a quem oprimir? Como contribuir para a emancipação enquanto elemento de transformação no processo educacional?

Konder $(1989$, p. 7) nos ensina que "escovar a história a contrapelo" é o elemento que "resume a postura de Benjamin diante de sua época, seu estilo de pensamento, bem como sua ação intelectual e política", porque não basta, de acordo com Konder $(1989$, p. 8), a respeito da advertência de Löwy, acreditar que, na obra de Benjamin, ser revolucionário e criticar o presente resolve o problema, mas não deixa de ser algo fundamental rever a história, contribuir para redimir o passado a fim de revolucionar o presente.

Dessa maneira, pode-se considerar, no sentido freiriano, que os opressores continuam a oprimir, especialmente quando permanecem os elementos que fazem o oprimido se identificar com o opressor e com ele continuar numa eterna guerra silenciosa, cujo mérito da vitória é apropriar-se da ignorância do oprimido. Os vencedores da história continuam a vencer, ainda que a glória da conquista capitalista signifique a perdição e a danação de muitos que sonham com a reparação da história; isto equivale a dizer, em termos adornianos, que não se repita Auschwitz, se é que ainda podemos dizer que Auschwitz continua a se repetir dadas as permanências históricas e a formação como semiformação, se replicando e fazendo perpetuar elementos que já deveriam estar ultrapassados numa sociedade que se diz esclarecida e "moderna".

\section{REFERÊNCIAS}

ADORNO, T. W. Educação e emancipação. Tradução: Wolfgang Leo Maar. 3. ed. São Paulo: Paz e Terra, 1995.

ADORNO, T. W. Dialética negativa. Tradução: Marco Antonio Casanova. Rio de Janeiro: Zahar, 1998.

ADORNO, T. W. Teoria da semiformação. In: PUCCI, B.; ZUIN, A. A. S.; LASTÓRIA, L. A. C. N. (Org.) Teoria crítica e inconformismo: Novas perspectiva de pesquisa. Campinas: Autores Associados, p. 7- 40, 2010.

ADORNO, T. W. Educação e emancipação. Tradução: Wolfgang Leo Maar. $7^{a}$ reimp. São Paulo: Paz e Terra, 2012.

ADORNO, T. W.; HORKHEIMER, M. Dialética do esclarecimento: Fragmentos filosóficos. Tradução: Guido Antonio de Almeida. Rio de Janeiro: Zahar, 1985. 
BENJAMIN, W. Magia e Técnica, Arte e Política. Ensaios sobre literatura e história da cultura Tradução Sérgio Paulo Rouanet; Prefácio de Jeanne-Marie Gagnebin. São Paulo: Brasiliense, 1994.

BENJAMIN, W. Passagens. Tradução: Irene Aron, Cleonice Paes Barreto Mourão, Willi Bolle, Olgária Chain Féres Matos. 2. reimpressão. Belo Horizonte, São Paulo: UFMG, Imprensa Oficial do Estado de São Paulo, 2009.

BENJAMIN, W. Magia e técnica, arte e política. Ensaios sobre literatura e história da cultura. Tradução: Sérgio Paulo Rouanet; Prefácio de Jeanne-Marie Gagnebin. 8. ed. São Paulo: Brasiliense, 2016.

BUBBO, D. As estruturas da reificação em curso: Walter Benjamin e Guy Debord, leitores de História e Consciência de Classe. Plural, São Paulo, v. 17, n. 1, p. 9-34, 2010.

CHAVES, E. Sexo e morte na infância berlinense, de Walter Benjamin. In: SELIGMANNSILVA, M. Leituras de Walter Benjamin. São Paulo: Annablume/Fapesp, 2007.

COLOM, A. J.; BALLESTER, L. Walter Benjamin: filosofia y pedagogia. São Paulo, Barcelona: Cortez, Octaedro, 2016.

FREIRE, P. Conscientização: Teoria e prática da libertação. Uma introdução ao pensamento de Paulo Freire. São Paulo: Centauro, 2008.

FREIRE, P. Educação como prática da liberdade. 36. ed. Rio de Janeiro, São Paulo: Paz e Terra, 2014a.

FREIRE, P. Pedagogia do oprimido. 57. ed. Rio de Janeiro: Paz e Terra, 2014b.

JAY, M. A imaginação dialética: História da Escola de Frankfurt e do Instituto de Pesquisas Sociais (1923-1950). Tradução Vera Ribeiro. Rio de Janeiro: Contraponto, 2008.

KONDER, L. Walter Benjamin: O Marxismo da Melancolia. Rio de Janeiro: Campus, 1989.

LÖWY, M. A filosofia da história de Walter Benjamin. Estudos Avançados, São Paulo, v. 45, n. 16, p. 199-206, maio/ago. 2002.

LÖWY, M. Walter Benjamin: aviso de incêndio: Uma leitura das teses "Sobre o conceito de história". Tradução: Wanda Nogueira Caldeira Brant, Jeanne Marie Gagnebin, Marcos Lutz Müller. São Paulo: Boitempo, 2005.

MATE, R. Meia-Noite na História: Comentários às teses de Walter Benjamin sobre o conceito de história. São Leopoldo: Unisinos, 2011.

RUSH, F. (org.). Teoria Crítica. Tradução Beatriz Katinsky e Regina Andrés Rebollo. Aparecida: Ideias e Letras, 2008.

WIGGERSHAUS, R. A Escola de Frankfurt: História, desenvolvimento teórico, significação política. Tradução do alemão Lilyane Deroche-Gurgeli, tradução do francês Vera de Azambuja Harvey. Rio de Janeiro: DIFEL, 2002. 


\section{Como referenciar este artigo}

AGOSTINI, Nilo; SILVA, Luzia Batista de Oliveira. Educação e Formação crítica na atualidade. Revista Ibero-Americana de Estudos em Educação, Araraquara, v. 14, n. esp. 4 , p. 1977-1992, dez., 2019. E-ISSN: 1982-5587. DOI: https://doi.org/10.21723/riaee.v14iesp.4.12922

Data de submissão: $25 / 06 / 2019$

Data de aceite: 20/07/2019

Data de publicação: 01/09/2019 